論文および報告

\title{
アーク溶接過程における水素の挙動（第 1 報）*
}

\author{
坪井潤一郎** 中野昭三郎** 佐 藤 功 輝**
}

The Behavior of Hydrogen in Arc Welding*

-Hydrogen absorption in arc melting-

by Jun-ichiro Tsuboi**, Shozaburo Nakano** and Koki Sato**

\begin{abstract}
An investigation is made on the hydrogen absorption in a molten pool of weld metal.

JIS hydrogen test has been commonly used for the quantitative analysis of diffusible hydrogen content in weld metal. It is found that the estimation of hydrogen content in a molten pool from this method is incorrect due to the dependency of the results on test conditions.

The causes are;

1) It must take more than $5 \mathrm{sec}$ after an arc off up to quenching a specimen in water.

2) . The hydrogen diffused from deposited to the base metal during welding is accounted for the greater part of hydrogen collected by this method.

From these resaons the new technique is devloped, which can measure the hydrogen content in a molten metal immediately after an arc off.

A specimen is melted by a tungsten electrode in $\mathrm{Ar}-\mathrm{H}_{2}$ mixture in a copper crucibles and tightly closed in it immediately after an arc off.

Hydrogen evolved from the specimen is laed to an oxidising furnace and accumlated in a cold trap as ice. The stored ice is determined by the volumetric analysis after its conversion to vapor.

The relation between hydrogen partial pressure in the arc atmosphere and absorbed hydrogen in a molten pool obeyed a law of square root within $\mathrm{P}_{\mathrm{H}_{2}}<0.2 \mathrm{~atm}$. in pure irons, low carbon steels, $1.7 \% \mathrm{Mn}$ steels, 18-8 and 15-35 stainless steels. Hydrogen absorption in the arc melting, if it corrected using activity coefficients of $\mathrm{C}, \mathrm{Si}, \mathrm{Mn}, \mathrm{Ni}$ and $\mathrm{Cr}$ on hydrogen, is nearly alike in every material and yield to Sievert's law in the temperature range of $2000 \sim 2200^{\circ} \mathrm{C}$, taking into account the acivities and steel making data.
\end{abstract}

\section{1. 緒 言}

溶接部の健全性に対して溶解水菜が重要な役割りを演 じていることはすでによく知られており，凝固後のアー ク溶接部に拈ける水素の挙動については，従来加らすぐ れた研究が多い，いっぽう，アーク溶接時の水素溶解に 関する研究は，それがアーク溶接現象を解明するための 1 つの重要な知見亡なるにもかかわらず，水素の著しい 移動性に加えて，その溶解量がアーク直下の溶融池での 溶解とその外緑部での放出とが釣合った定常状態として しか求められないなど，多くの実験的困難さのために比 較的少ない現状である.

*原稿受付 昭和 47 年 8 月10日（46.47年秋李大会比発装）

**IIE 員川崎製铁(株) Member, Research Laboratories Kawasaki Steel Corp.
J I S 亿定められた溶接金属の拡散性水素試験梳，溶 接部のわれ感受性に対する評価を対象としたものであ り，必ずしも溶融金属に溶解した水素睹を正確に表わす 6のではない．しかし．乙の方法澡作が簡便で．溶接 われに対する工学的な比較試験法として広く実施されて いるから，乙の測定結果に影響を与える各種の要因を明 確にし，また剆定結果上溶解水素量との関連を明ら汃に しておくことは，施工上でも必要なととと考えられる。 かかる観点から J I S 亿定められた拡散性水菜試験法 が溶融金属の溶解水菜量をどの程度推定する手段となり うるかを調べるために，との試験法の境界条件に対して 検討を加えた. その結果 J I S 法あるいはその改良法で は，溶融金属中の溶解水素量を正確们測定するととは困 難であるてとがわかったので溶解水素量を正礶们測定で きる専用の装置を製作し，乙の装置による各種溶融金属 
Table 1. Procedure of JIS diffusible hydrogen test.

\begin{tabular}{|c|c|c|c|c|c|c|}
\hline \multicolumn{2}{|c|}{ Specimen } & \multicolumn{3}{|c|}{ Welding conditions } & \multicolumn{2}{|c|}{ Quenching conditions } \\
\hline Preparation & Size & Size & Current & Bead length & Water temp. & Time to quenching \\
\hline $\begin{array}{l}600^{\circ} \mathrm{C} \times 1 \mathrm{~h} \\
\text { degassing }\end{array}$ & $\begin{array}{l}12 \times 25 \\
\times 130 \mathrm{~mm}\end{array}$ & $5.0 \mathrm{~mm} \phi$ & $\begin{array}{c}170 \\
210^{\prime} \mathrm{A}\end{array}$ & $115 \mathrm{~mm}$ & $20^{\circ} \mathrm{C}$ & $\begin{array}{l}\text { Within } \\
\text { 30s }\end{array}$ \\
\hline
\end{tabular}

\begin{tabular}{c|c|c|c|c}
\hline Time to setting & Extracting conditions & No. of runs & Dimensions \\
\hline $\begin{array}{c}\text { Within } \\
\text { 120s }\end{array}$ & $\begin{array}{c}48 \mathrm{~h} \text { in } 45^{\circ} \mathrm{C} \\
\text { glycerin }\end{array}$ & 4 times & ml/100 g dep. metal \\
\hline
\end{tabular}

への溶解水菜量测定結果について考察を加えた.

\section{JIS 抎散性水素試験法の検討}

\section{1. 実験方法}

Table 1 亿示す J I S 法を標準条件とし, 溶接金属中 の拡散性水素量に対する溶接時間, 溶接㣠了加ら水冷ま での時間招よび試験片板厚などの効果を，拡散性々非拡 散性水素にわけて，それぞれ定量して調べた．さらに銅 製治具を用いて純溶着金属中の水素量も測定して J I S 法との比較を行った。

\subsection{1. 供試材之溶接条件}

Table 2 亿示す組成の鋼板を $800^{\circ} \mathrm{C}$ で1時間脱ガス 処理を行なって試験用母材とし， $4 \mathrm{~mm}$ 径のライムチタ ニヤ系被覆アーク溶接棒を $80^{\circ} \mathrm{C}$ で 1 時間乾燥して供試 した.

Table 2. Chemical composition of base metal (\%).

\begin{tabular}{c|c|c|c|c}
\hline $\mathrm{C}$ & $\mathrm{Si}$ & $\mathrm{Mn}$ & $\mathrm{P}$ & $\mathrm{S}$ \\
\hline $\mathbf{0 . 1 4}$ & 0.32 & 1.08 & 0.015 & 0.012 \\
\hline
\end{tabular}

水素試験結果は, 溶接時の大気中の水蒸気分圧によっ て变化するから，乙てでは実験室全体を気温 $25^{\circ} \mathrm{C}$, 相 対湿度65\%になるように空気調節して試験を行なった。

\subsection{2. 水素の捕集, 定量方法}

試験片は溶着終了から 0 64 $\mathrm{s}$ の所定時間放置後ただ ちに氷水中に冷却し，付着したスラグやスパッタを除去 した水菜捕集瓶中に扱入した，水冷開始加ら捕集瓶に插 入するまでの時間は $40 \mathrm{~s}$ 一定とした.

水素には鍓中を自由に搪散できるものと，各種欠陥な どに捕捉されているすのとがあるが，とれらをそれぞれ 搪散性と非搪散性の水素として別個任定量した。

（1）抎散性水菜の定量方法

J I S 法にしたがって, Fig. 1 亿示すように $45^{\circ} \mathrm{C}$ に 保った水素飽和グリセリン浴中で試験片加ら放出される ガスを48時間捕集して拡散性水素量とした.

（2）非拡散性水素の定量方法

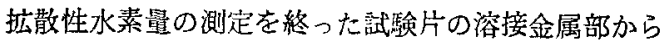

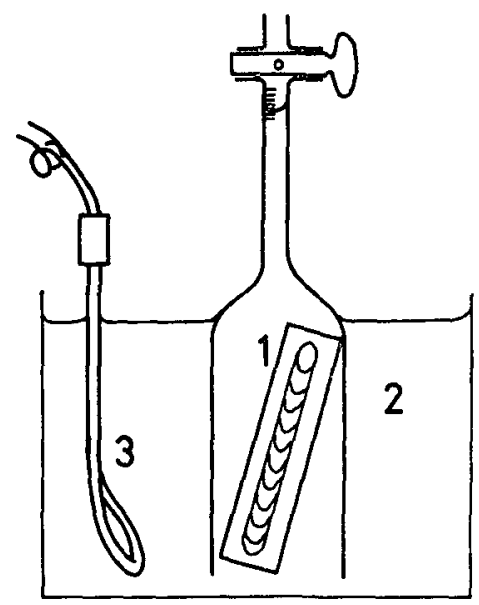

Fig. 1. Apparatus for JIS diffusible hydrogen test. 1: Specimen

2: Glycerin

3: Heater and regulator

$3 \times 10 \times 15 \mathrm{~mm}$ 亿切出した試料 2 個を用いて非抬散性水 素を測定した．定量にはスズ浴溶融熱伝導度法(サーミ スタ法）を採用した。乙の方法は，約 $1100^{\circ} \mathrm{C}$ 亿保持し たアルミナルツボ中のスズ浴に試料を投入して真空溶融 でガスを抽出する方法で. この抽出ガスは $\mathrm{CO}, \mathrm{N}_{2}, \mathrm{H}_{2}$ であるがその熱伝導度が前2 者は近似し， $\mathrm{H}_{2}$ は著しく 大きいから，サーミスタを用いて $\mathrm{H}_{2}$ の熱伝等度からそ の量を定めるすのである．分析誤差は通常の鋼中含有量 の場合では $\pm 0.1 \mathrm{ppm}$ 程度である。

\section{2. 水素試驗結果}

2.2.1. 鋼板上ビード溶接における水菜量

Fig. 2 は一定溶接速度 $3.8 \mathrm{~mm} / \mathrm{s}$ で溶接時間を 5 , 10，20，30s 亿変化した場合の拡散性水素量におよばす 溶接終了から水冷までの放置時間の影響を示す一例であ る. 水素量は溶着金属 $100 \mathrm{~g}$ に対する標準状態に換算 した放出ガス量を $\mathrm{ml}$ で表わした.

また，同図には溶接時間 $30 \mathrm{~s}$ の場合の非拡散性水素 量およびビード中央部中心点とそとに対応した試験片裹 
面の温度変化もあわせて示した. ビード中央部の冷却曲 線は, アーク通過直後にタングステンータングステンレ 二ウム熱電対を溶融池に插入して测定したものであり， $1000^{\circ} \mathrm{C}$ 以下の温度は別の試片を用いてクロメルーアル メル熱電詨と対比補正を行なった。

四から明らかなように，水素試験片の温度はアーク通 過後 $10 \mathrm{~s}$ から $60 \mathrm{~s}$ までは $600 \sim 900^{\circ} \mathrm{C}$ であり, 溶接 ビード部の温度はその高温側にあると考えられるから， ビードの温度变化は消弧後 $60 \mathrm{~s}$ 間でたかだか $200^{\circ} \mathrm{C}$ 程 度であると推定できる。

拡散性水素量は消弧後 $5 \mathrm{~s}$ 以上の時間経過にしたがっ て明らかに減少するが，非拡散性水素量は放置時間に関 係なくほぼ一定で，その量も溶接時間にかかわらず非常 に少ない。

消弧直後に水冷した場合には，Fig. 2 の 4 s の測 定值が示すように，かえって拡散性水素が減少する結果 となった．消砆後 $4 \mathrm{~s}$ 以前には溶接金属の一部がいまだ 溶蠤状態にあって，水冷時にはこの部分の試験片からの 飛散が認められ，水素濃度が最も高いこの部分の飛散が 上述の水素量の見挂けの減少を示したと考えられる.

このため, 放置時間 $5 \mathrm{~s}$ 以後の水素量減少曲線を甸配 一定のまま延長し, 凝固直後の溶解水素量を推定し,

Fig. 2 の曲線(日)得た. (Aはもち万ん正確な水素量で はなく実際にはとれ以上の水素が溶解していると思われ るが，(A) と放置時間 $30 \mathrm{~s}$ のものを比較すると後者は前 者の50〜60\%にすぎない。

Fig. 3 は, 溶接時間が拡散性水素試験結果におよぼ す影㸷を示したあのである．乙の結果も消弧後の放置時 間関係なく(®と同じく溶接時間 $20 \mathrm{~s}$ の場合に最大值 を示した。この原因は，溶接時間の短かいものは，とけ とみが小さく試験片の温度む低いため, 後述するように

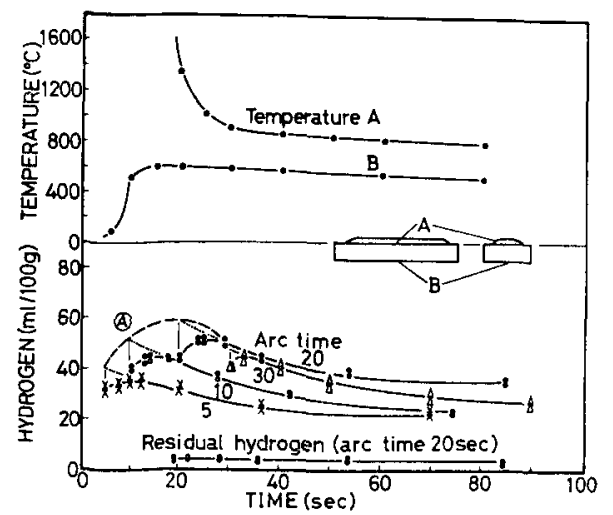

Fig. 2. The effect of arc time and quenching time on the diffusible hydrogen.

(D 4303 electrode, arc current 170A, welding speed $3.8 \mathrm{~mm} / \mathrm{s}$ )
水素吸収量や溶接金属から母材への拡散水素量が少ない ためであり，長時間溶接のもの溶接中に先に凝固した 溶接金属から大気中に逃散する水素量が増大したため に，昖散性水素量の測定值は少なくなったと考えられ ろ.

J I S法では拡散性水素鼍は溶着金属 $100 \mathrm{~g}$ に対し て表示するが，実際には母材溶融部や熱影響部へ拡散し た水素量がかなり多く，溶込量が異なる場合にはその補 正が必要である之考えられる.

同一組成の板厚 $20 \mathrm{~mm}$ の鐥板を $16 ， 12 ， 6$ および $3.2 \mathrm{~mm}$ に減厚して, 板厚のみを変化した場合の水素量 を比較した。試験は溶落ち防止のために試験片を $40 \times$ $40 \times 130 \mathrm{~mm}$ の銅板にうめこみ, 溶接時間 $20 \mathrm{~s}$, 消弧後

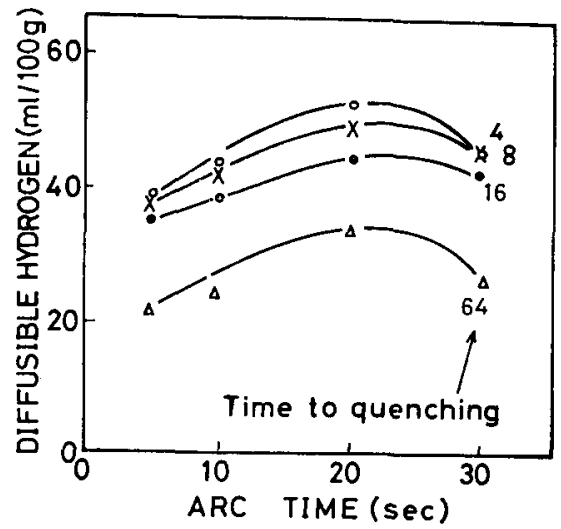

Fig. 3. Arc time and dffusible hydrogen. (D4303 electrode, arc current 170A, welding speed $3.8 \mathrm{~mm} / \mathrm{s}$ )

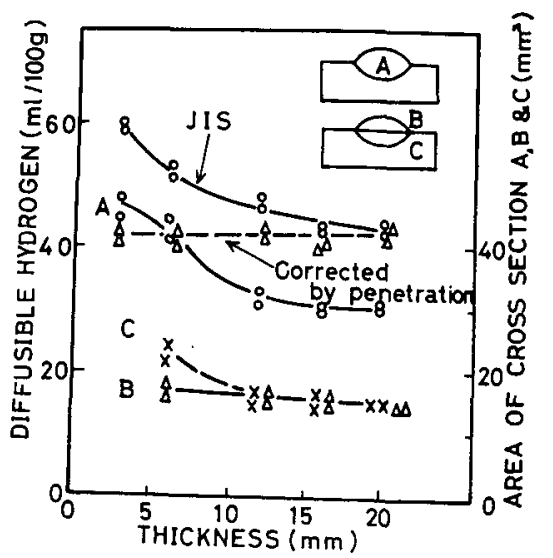

Fig. 4. The effect of specimen thickness in the diffusible hydrogen by the JIS method and correction by penetrations.

(D4303 electrode, arc current 170A, welding speed $3.8 \mathrm{~mm} / \mathrm{s}$ ) 
水冷までの時間 10 s で行なった.

板厚と溶込量および拡散性水素量との関係は Fig. 4 のようになり，溶込量の補正を行なわないJ I S 法によ る表示では拡散性水菜量は板厚が增すにつれて減少した が，溶込量を含めた溶接金属 $100 \mathrm{~g}$ あたりで示せば，水 菜量は板厚に関係なくほぼ一定值を示した。

\subsection{2. 純溶着金属の拡散性水菜量}

J I S法では, 溶接の進行に伴って水䒺は熱影響部へ 昖散するとともにビード表面から大気中へ逃散し，また 溶込量そのもの対する考虑を必要とするから，アーク 溶接時の溶融金属への溶解水素量を精度よく推定するこ とは因難である、ここでは，熱影響部への昖散量および 母材への溶込量を取除いて害際に溶解する水素量をでき るだけ単純に評洒する目的で, 二種類の銅製鋳型上に溶 着金属を溶着して拡散性水素量を测定した.

（1）ビード型純溶着金属の抬散性水素量

Fig. 5(a) に示すV瑇をつけた $15 \times 40 \times 140 \mathrm{~mm} の$ 銅板上に溶着したとき，消弧後水冷までの放置時間之拉 散性水素量との関係住 Fig. 6 のようになり, 水素量は 鏰板上に溶着した場合の数分の一で非常に少ない值を示 した.

（2）溶滴型純溶着金属の拡散性水素量

上述のビード型試験法では，溶着の進行に伴って溶融 池以外のビード部は凝固冷却してガスを逃散させるか ら, 溶融状態での溶解水素量を分離して評洒するととは 困難である．そこで，溶融池に打ける溶解水素量を測定 するために，Fig. 5(b) の溶滴型銅製鋳型を用いてビー ド型の場合と同じ条件で水素試験を行なった. その結果 は Fig. 6 に示すように, 予期に反してビード型の水素 量よりもさらに低い值を示した，乙れは溶滴が大きす ぎ,アークに直接さらされた溶解面積に比べてアーク外 縁で水素が逃散する面積がかなり大きく，またビード型 よりあ試料全体が平均して高温であるために，大気への 逃散水素量が多くなったためと考えられる。

以上のように純溶着金属法を用いても，水素の物質収 支を定量化するには多くの問題が残されるととがわかっ た.

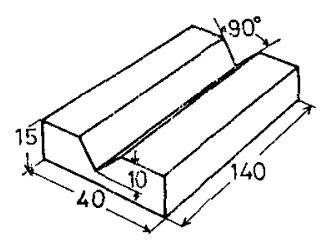

(a) bead type (b) drop type

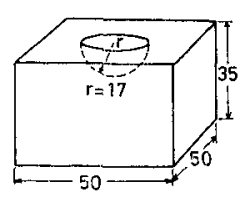

Fig. 5. Copper jigs for measuring hydrogen in pure weld metal.

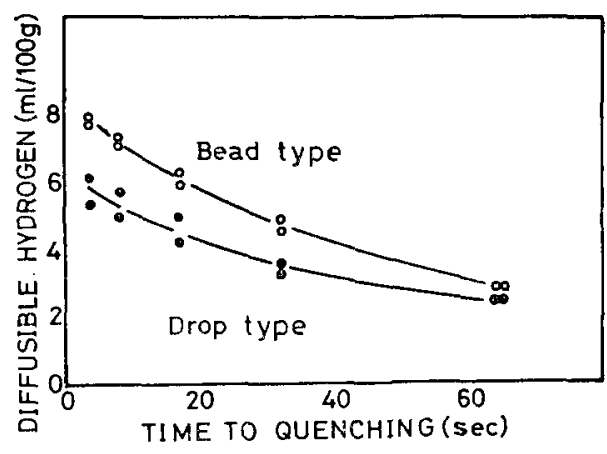

Fig. 6. The diffusible hydrogen of pure weld metals in two type copper jigs.

(D4303 electrode, arc current 170A, welding speed $3.8 \mathrm{~mm} / \mathrm{s}$ )

\section{3. 考察}

現在, 溶着金属中の拡散性水素量測定法として広く用 いられているJ I S 法は，消弧後の放置時間を $30 \mathrm{~s}$ 以 内として，汃溶着金属 $100 \mathrm{~g}$ あたりの水素量で表示 するように定められている.

Fig. 2 から, 放置時間が $30 \mathrm{~s}$ の測定值之最大の水素 量を示す $5 \mathrm{~s}$ の値を比較する之，前者は後者の60 70\% にすぎない，消弧時の水素量を知るためには，操作の許 すかぎり放置時間が短かいほど望ましいが，消抔後ただ ちに水冷すれば前述のようにいまだ溶融状態で水素を最 屯多く含む部品が試験片加ら取除かれて，放㯰時間が $4 \mathrm{~s}$ 以下の場合の測定結果はかえって減少するから, 水 冷法を用いるかぎり放置時間 $5 \mathrm{~s}$ 以上の水素量減少曲線 から溶解水素量を推定せざるを得ない．しかす，ての 推定值は溶融池が疑固した直後の溶解水素量であり， J I S 法の目的であるわれ感受性の評伍には有力ではあ るが, 溶融状態での溶解水素量を示すすのではない.

な招捕集した水素量の換算にさいして，単位溶着金属 あたりとすべきか，溶込みを考えた単位溶接金属重量苟 たりとすべきかは，ア一ク溶接時の水素の溶解過程とあ 関連する. 水素溶解が棒端あるい传移行溶滴で行なわれ るならば試験片に与えられる水素量は，すべて溶着金属 からもたらされるものであるから，単位溶着金属あたり を考えればよい．また溶融池での水素吸収が支配的であ るとすれば，溶込みを考慮して単位溶接金属あたりとす る必要がある、本実験では単位溶着金属あたりの㹡散性 水素量は試験片の板厚によって大きく变化したが，溶込 みを考慮すれば板厚の影響はなくなり，一定の水索量を 示したから，水素量は溶接金属代対して評価するほうが 正しいと考えられ，さらに，水素溶解には溶融池での反 応が支配的であると推論できる。

アーク溶融された溶融池にどれだけの水素が溶解して 
いるかは，J I S 法のように母材を用いる試験法では测 定できない，すなわち，アークにさらされて活性化した 溶融池には多量の水素が溶解しており，溶接が進むにつ れて母材や外気に抁散して行くが，てれらの水素の移動 を理諭的加定量的化追究するととは極めて困難であ る. 溶着終了時に試験片に残存する水素量は，Fig. 2 のように溶接時間によって変化するが，乙れは試験片全 体を平均して考えたものであり局部的な物質収支を正し く累積した結果でなく，また溶接速度によっても変化す る上考えられる.

Fig. 7 は銅板上で溶着したビード型綕溶着金属法と J I S 法とによる拡散性水素量の比較であり，溶込みを 考虑してあな拈 J I S 法のほうが数倍多く，てれは溶接 中に溶融金属加らかなり多量の水素が母材へ拡散してい ることを示唆している. 消弧時の溶融池の水素量を知る ためには，前述のようにビード型試験よりも溶接金属全 体が溶融している溶滴型試験のほうが望ましいが，いず れの方法でも水冷を用いるから消弧後捕集開始までに時 間を要し，測定値がただちに溶融池の水素量を示してい るとは考えられない，また溶滴型としても溶鋼量が多い 之溶解域に刘する逃散域の面皘が過大となり水素量の測 定値は減少するから，適正な溶着量を選定する必要があ る.

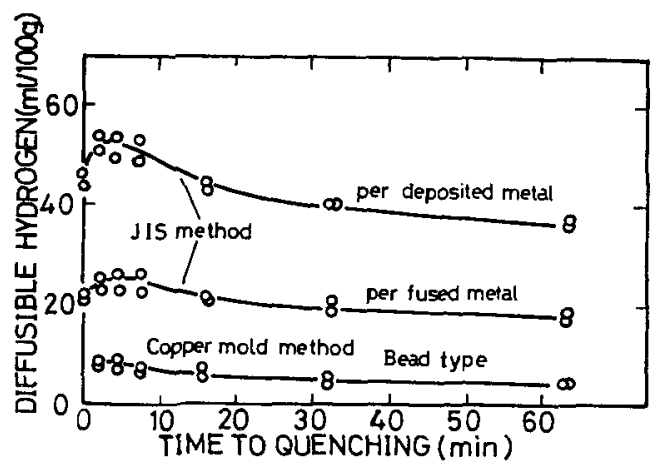

Fig. 7. Comparison between JIS method (welding on the base metal) and pure weld metal method (welding on the copper jigs).

以上の考察加ら溶融金属中の溶解量の測定には，J I $\mathrm{S}$ 法でも本節で用いた純溶着金属法であ不十分であるこ とがわかる.

\section{4. まटめ}

被覆厂ーク溶接棒に上る溶着金属の拡散性水素試験を 溶接時間，消弧後水冷までの放置時間，板厚などを変化 したJIＳ法および銅製治具を用いた純溶着金属法によ って行ない,つぎの結論が得られた。

1. J I S 水素試験結果は，標準溶接速度で溶接時間
20 s の時に最高值を示す.

2. $30 \mathrm{~s}$ 放置後の掂散性水素量は，凝固直後の溶解 水菜量の 60 70\%程度に減少している. てれに対し て, 非拡散水素量は放置時間に関係なくほぼ一定値 を示し，その量む非常飞少ない。

3. J I S 水菜試験片の板厚の影響は, 溶着金属重量 基準で表示すれ代顕著であるが，溶込みを考虑して 溶接金属規準で表示すれば認められず，拡散性水素 量を板厚に無関係に評価するととができる.

4. 銅製治具を用いた純溶着金属の拡散性水素量の測 定値は J I S 法の数分の 1 にすぎず，J I S法では 相当量の水素が母材へ拡散していることが予想され る.

5. J I S水素試験は，われ感受性の評価のためのも ので，その試験結果から溶融池の溶解水菜量を予測 するととは困難である．純溶着金属法を用いてす水 素の溶解域之逃散域の比率およびそれらの温度に上 って, 水菜量の測定値は非常に暴なるから, 溶融池

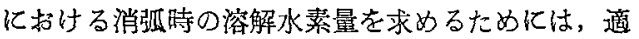
当量の溶着金属を水冷処理を行なわずに消弧之同時 に測定が始められる装置が必要である.

\section{3. アーク溶融鋼の溶解水素量 測定装置の製作}

J I S 拡散性水菜測定法では，溶融鋼中の水素量を正 確に推定することは困難であることを前節で示した．本 節では, $\mathrm{Ar}-\mathrm{H}_{2}$ 雾团気でT I G 溶解したときの溶解水 菜量測定装置について述べる。

\section{1. 测定茭置の概略}

アーク溶融した溶鐦中の水素は, 稲垣ら1), Salter 2), Howden ら3によって測定されているが, いずれも 異なった手法を用いている。稲垣らは Fig. 8 のよう に, 雾囲気調整した溶瀜室内でT I G溶融した試料を 消弧後ただちに自由落下せしめ，急冷室で泠却して放 出される水素をガスクロマトグラフで定量している， Salter は Fig. 9 に示方銅製アーク溶融焒中でT I G 溶接トーチを用いて試料を溶融し，消弧後密閉して 放出されるガスをカタロメータで積分定量している. Howden らはこれらと異なり Fig. 10 のように密閉さ れた容器中でアークを点じ, 雺围気ガスの水素濃度の減 少から溶解水素を定量しだ.稻垣, Salter の方法はと るに消弧後の水素の発生量を測定しているのにくらべ， Howden の方法はアーク発生中に水素の溶解量を測定 している点で合理的と思われる.

本節で述べるあらたに製作した製置では，アーク溶融 炉内の残留水素の除去疑縮水分の回避の点に扣いて 


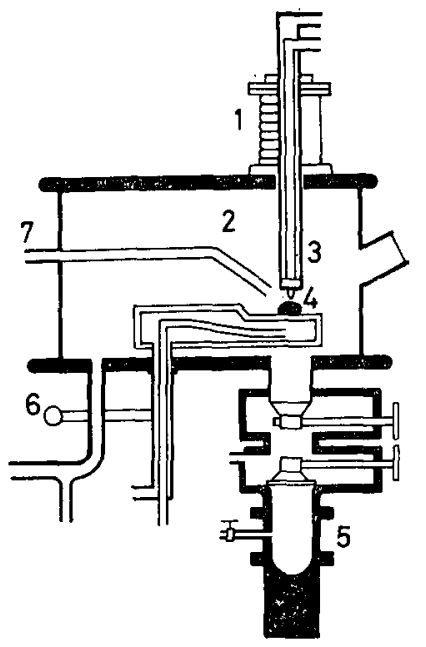

Fig. 8. An apparatus of INAGAKI et al.

1: Bellows

2: Melting chamber

3: Tungsten electrode

4: Specimen

5: Quenching room

6: Rotating handle

7: Shielding gas nozzle

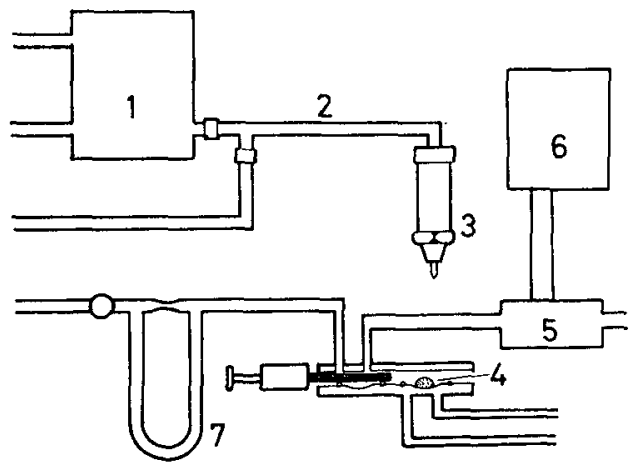

Fig. 9 An apparatus of SALTER
1: $\mathrm{Ar}-\mathrm{H}_{2}$ mixer
2: Shielding gas
3: Torch
4: Specimen
5: Katharometor
6: Recorder
7: Manometer

Salter のものを改良し，捕集に対しては放出水素を水 としてガラス管に蓄積する独自の方法を用いて，放出水 素の全量を確実かつ簡単に定量できるようにした。

実験誤差については，測定部のみの愦差を $\pm 1 \%$ 以下 に捕集部を含めてす $1.5 \%$ 以下にするてとを目標にし て, 配管やガラス管径扰よび外気の造閉に留意した。

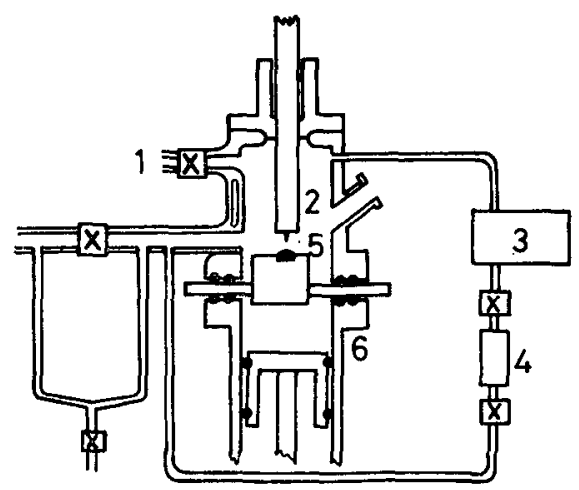

Fig. 10. An apparatus of HOWDEN et al.

1: Gas inlet, out let

2: Torch

3: Katharometer

4: Diaflam pump

5: Specimen

6: Sliding cylinder

装置は Fig. 11 に示すように，銅製アーク溶融炉 5 でTＩＧ溶融した試料を消弧後ただちに密閉し，発生す るガスを洗浄部 1〜4を通ったキャリヤガス Ar を用い て酸化炉 6 飞送り，水蒸気として冷却ガラス管 7 の中に 凍結させ蓄積した。

試料からのガス放出が無視できるようになったのち， ガラス管を加熱し蓄積した水分を気化させて，その体樻 と任力とから放出水素量を定量できるようにした。

\subsection{1. 銅製了一ク溶融炉}

Fig. 12 は溶融炉の詳細で，(a)はアーク溶融時， （b）は水素捕集時を示している. 試料の溶融には市販 の I I Gトーチを用い，これから所定の比率任混合した $\mathrm{Ar}-\mathrm{H}_{2}$ を流すととによって溶融雾团気の調節を行なっ た.タングステン電極は $2 \mathrm{~mm}$ 径のあのを用いて，て れを陰極とした。溶㓲室14で溶融された試料は，消弧後 ただちに溶融疤の上ぶたを滑らせて溶融室内に密閉し た.

このとき溶瀜室内に残存している水菜は，清浄な Ar で置換する必要があり，てのために点弧中も/ズル12か ら高速多量の清净 Ar を流しておき，上ぶたの移動とと あに12からの Ar で溶融室内を清净化した，てのAr流 量を $4 \mathrm{l} / \mathrm{min}$ とすれば，アークを点じない状態のとき， $\mathrm{Ar}-20 \% \mathrm{H}_{2}$ 霛国気で $0.6 \mathrm{ml}$ あった残存水素量は上述 の操作によって $0.04 \mathrm{ml}$ まで減ずることができた。ア 一ク溶融を行なった場合には，吻体温度の上昇や溶融金 属体積による空間部の減少のために，残存水菜量はさら にこの約1/3に減ずると期待できる.

また，溶融炉の冷却に温水を用いれば水素の燃䡒によ 


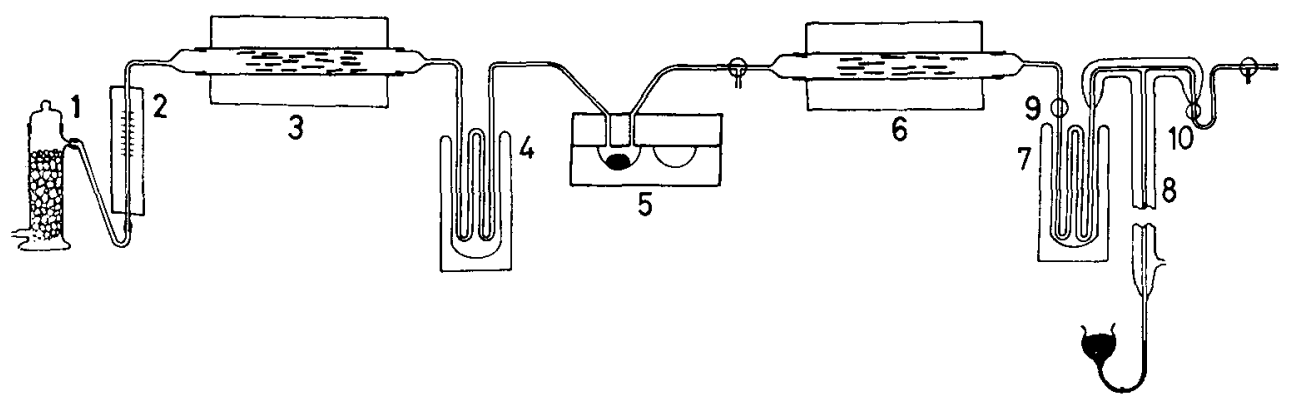

Fig. 11. An apparatus for measuring absorbed hydrogen in this experiment.

1: Magnesium perchlorate

2: Flow meter

3: CuO furnace

4: Dry ice alcohol bottle

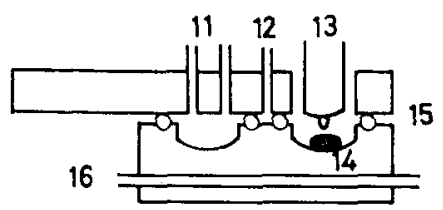

(a)

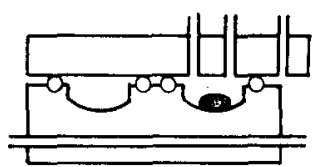

(b)

Fig. 12 Detail of arc melting furnace.

11: Carrier gas inlet \& outelt

12: Purge gas nozzle

13: Torch

14: Specimen

15: $O$ ring

16: Cooling water

って生ずる水蒸気の凝縮を防止することができる.

\subsection{2. 水素の定量}

試料から発生した水素は，キャリヤガスによって酸化

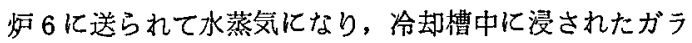

又管に凍結捕集される，乙のさい，冷媒としては凝固時 に発生する CO $\mathrm{CO}_{2}$ などの混入を防ぐためにドライ アイスアルコールを用いて，ガラス管を $-70 \sim-72^{\circ} \mathrm{C}$ に保った。

水素の捕集が終った時点で凍結させたままコック9を 閉じ，コック10から管内を真空にしたのちこれを閉じ る.コック 9 からコック10までの死容積をあらかじめ測 定しておけば，ての部分を加熱して水分を気化させて水 銀マノメータにより王力をは加り，捕集した水蒸気の体 積は次式によって算出できる.
5: Arc melting furnace
9: Cock
6: Oxidising furncae
10: Cock
7: Dry ice alcohol bottle
8: Manometer

$$
v=(V+\Delta l \cdot S) \cdot(\Delta l / 76) \cdot 273 /(273+t)
$$

ここで,

$$
\begin{aligned}
& v: \text { 捕集水素量 }\left(\mathrm{ml} \text { at } 0^{\circ} \mathrm{C}, 1 \mathrm{~atm}\right) \\
& V: \text { 測定部死容積 }(10.02 \mathrm{ml}) \\
& \Delta l: \text { 蒸発前後のマノメータのヘッド差 }(\mathrm{cm}) \\
& S: \text { マノメータの断面積 }\left(0.0079 \mathrm{~cm}^{2}\right) \\
& t: \text { 測定部の加熱温度 }\left({ }^{\circ} \mathrm{C}\right)
\end{aligned}
$$

上式を適用するためには，凍結された水分を完全に気 化する必要があり, 測定部の容積 $V$ と加熱温度の選定 が問題になる、たとえば本装置では $V$ を約 $10 \mathrm{ml}$ に設 計したから，標準状態で $1 \mathrm{ml}$ の水素を测定するとすれ ば, 測定部の圧力は $1 / 10 \mathrm{~atm}$ になり，この正力は水の $48^{\circ} \mathrm{C}$ の蒸気圧に相当するので, 完全に気化させるため には测定部全体をこの温度以上に显温しなければならな W.

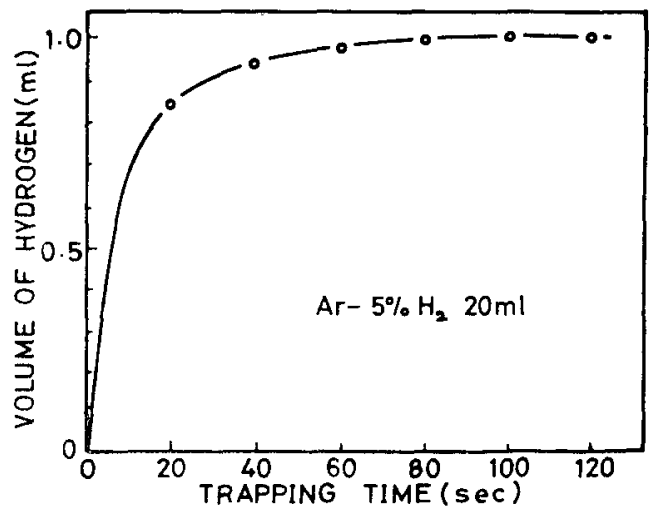

Fgi. 13. The effect of trapping time on collection of evolved hydrogen.

(addition of $20 \mathrm{ml}$ of $\mathrm{Ar}-5 \% \mathrm{H}_{2}$, carrier gas flow rate $100 \mathrm{ml} / \mathrm{min}$ ) 
Table 3. Calibration of apparatus.

\begin{tabular}{l|c|c|c|c|c|c|c}
\hline \multicolumn{2}{c}{$\begin{array}{c}\text { Charged volu me }(\mathrm{ml}) \\
\begin{array}{l}\text { Measured } \\
\text { volume(m) }\end{array}\end{array}$} & 0.20 & 0.40 & 0.60 & 0.80 & 1.00 & 1.50 \\
\hline
\end{tabular}

\subsection{3. 捕集時間}

溶融室で放出された水素は，配管を通って測定部に蓄 積されるが，溶融室内の水素が完全に Ar と置換される までには時間を要し，とれと捕集量の関係を Fig. 13 に 示す.

四は $\mathrm{Ar}-5 \% \mathrm{H}_{2} 20 \mathrm{ml}$ を溶融室に添加したときの捕 集量の時間変化であり，60s で97\%を，120 $\mathrm{s}$ でほぼ添 加全量を捕集できるととがわかった。

\section{2 装置の検定}

Ar-5\% $\mathrm{H}_{2}$ の標準ガスを注射器で㐫定量採取して溶 融室に注入し， $80 \mathrm{ml} / \mathrm{min}$ ○キリヤガスを用いて装置 の祫定を行なった。

Table 3, Fig. 14 がその結果で, $70^{\circ} \mathrm{C}$ の温湯で測定 部を加熱した場合は，添加量上測定量はきわめて良く一 致した．添加量の多少にかかわらず，それと測定量の差 は $0.01 \mathrm{ml}$ 以下であり, 本実験での溶解水素量は最大 $1.5 \mathrm{ml}$ と推定されるから，乙の装置は精度上十分使用 できることがわかった. $60^{\circ} \mathrm{C}$ 昇温の場合は, $0.6 \mathrm{ml}$ 以 上の添加量で直線からずれ，乙れ以上の水素量にたいし ては，さらに高温に加熱する必要があるととを示した。

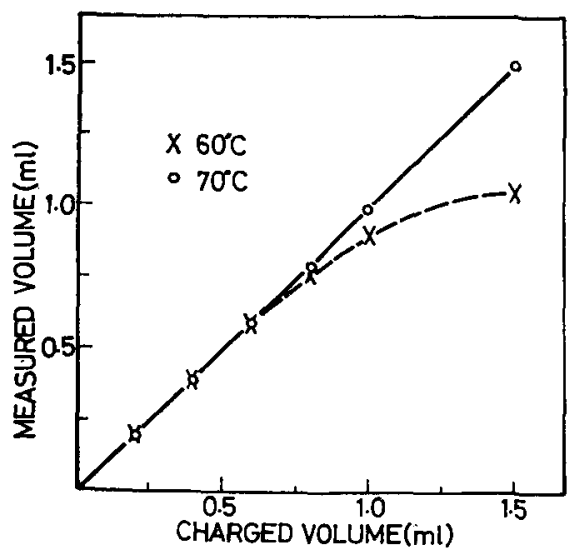

Fig. 14. Calibration curve.

\section{3 試料棗量の影響}

試料重量を $2 \mathrm{~g}$ 加ら $8 \mathrm{~g}$ まで変化させて, 溶解水素 量を調べたところ，Fig. 15 亿示すように試料 $100 \mathrm{~g}$ あ たりの捕集水素量は試料が大きくなるほど減少し， $5 \mathrm{~g}$ 以上でその傾向は少なくなる，図中に併記した Salter の測定値を換算した結果も完全に本実験結果と一致し

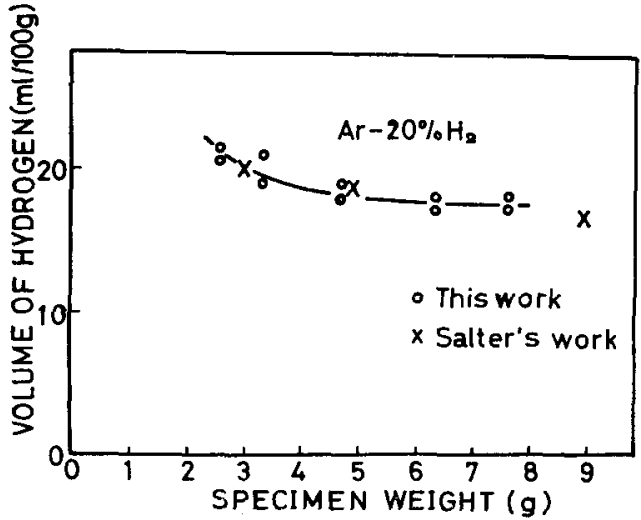

Fig. 15. The effect of specimen weight on the absorbed hydrogen.

(arc current $150 \mathrm{~A}$, arc time $30 \mathrm{~s}$ )

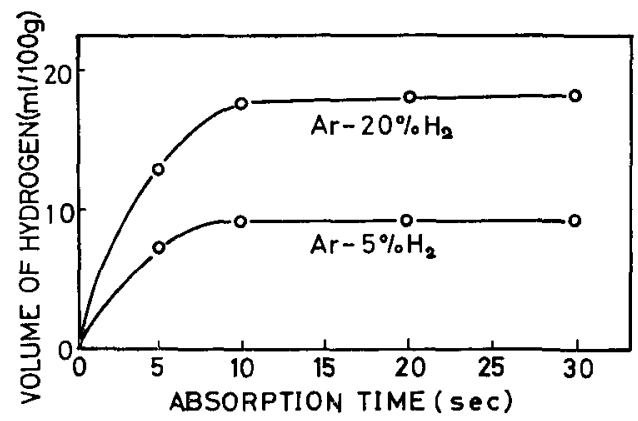

Fig. 16. The effect of arc time on the absorbed hydrogen.

(arc current 150A, specimen weight $7 \mathrm{~g}$ )

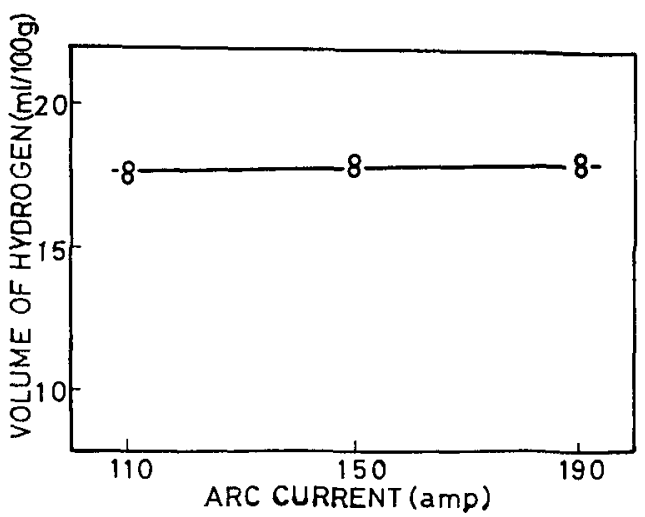

Fig. 17. The effect of arc current on the absorbed hydrogen.

(specimen weight $7 \mathrm{~g}$, arc time $30 \mathrm{~s}$ ) 
た、溶融室容積からは最大 $8 \mathrm{~g}$ までの制限があるので本 装置での試料重量は $7 \mathrm{~g}$ を最適とした。

\section{4 溶融時間の影響}

試料の溶融時間と水素量の関係を Fig. 16 亿示す. 溶 融時間としては，アーク点张後の時闒をとったが，目視 観察では約 $5 \mathrm{~s}$ で試料はほぼ完全に溶融した. $7 \mathrm{~g}$ の試 料を用いたとき，霓囲気の水菜濃度に関係なく $10 \mathrm{~s}$ で 捕集水素量は一定になった。

\section{5 溶接電流の影辈}

溶融に用いるアーク電流を変化させると，Fig. 17 に 示すように，捕集水菒量は笔流によってわずかに増加し た.しかし，その堌加率は $0.0038 \mathrm{ml} / 100 \mathrm{~g} \cdot \mathrm{A}$ にすぎ ないから，本装置では電流を一定值 $150 \mathrm{~A}$ で使用すれ ば $110 \mathrm{~A}$ から $190 \mathrm{~A}$ までの溶解水素量を精度よく示し ていると考㫕られる。

\section{6 まとめ}

アーク溶融した溶鐲中の水素溶解舅を测定する装置を 試作して，つぎの条件範囲を用いれば最適であるととが わかった。

1. 試作測定装置は, $0.2 \mathrm{ml}$ 加ら $1.5 \mathrm{ml}$ の水素量 の範囲ではその多少を問わず， $0.03 \mathrm{ml}$ 以下の詔差 で溶融, 凝固, 冷却の各適程を含めた放出水量を測 定できる.

2. 溶鋼単位重量あたりの放出水素量は, 試料重量が 増すにつれて減少するが，5g 以上になるとその傾 向はゆるやかになり，溶融室溶樍からの制限之あわ せて，試料重量は $7 \mathrm{~g}$ が適当である.

3. 淙囲気の水素濃度にかかわらず，溶解水素量はア 一ク点弧後 $10 \mathrm{~s}$ ですべて飽和する.

4. 溶解水素量はアーク電流の增加によもなって, $0.0038 \mathrm{ml} / 100 \mathrm{~g} \cdot \mathrm{A}$ だけわずかに増加する.

\section{4. アーク溶融金属の水素溶解量}

前節で述べた測定装置を用いて各種溶融金属中の水素 溶解量を測定した.

\section{1 実験方法}

試料として電解鉄，低炭素銚， $1.7 \%$ マンガン銝招よ びステンレス鍓（18Cr-8Ni，15Cr-35Ni）をあらかじめ
Ar 雲囲気中でアーク溶融して，7.0土0.2g のボタン状 にしたすのを用いた．その化学組成を Table 4 に示す.

アーク溶融はＴＩＧトーチを用い，雾囲気ガス流量を $15 \mathrm{l} / \mathrm{min}$, 溶接電流を D.C., S.P. $150 \mathrm{~A}$, アーク長を 5 $\mathrm{mm}$ 亿して行なった。アーク点胧後, 試料が全部溶融す るには約 $5 \mathrm{~s}$ を要するが,さらに $25 \mathrm{~s}$ 継続点弧して， 雲囲気ガスの $\mathrm{P}_{\mathrm{H}_{2}}$ と水素溶解が定常状態に達するに十 分な時間をあたえた。

アーク消弧後，ただちに上ぶたを滑らせて試料を密閉 し，放出ガスを Arキャリヤガスで测定部に移した．上 ぶたを移動し終る時刻は，消张後 $0.2 \mathrm{~s}$ 以内で，この上 きキャリヤガス管に先行したノズルから Arを高速度で 多量僨射させて溶融炣内に残留した霛囲気を除去し tェ.

水素の定量は，前節で述べた手順にしたがって行な い，水素の放出がほとんど終了した試料は Fig. 18 の I I W式拡散性性水菜測定装置にただちに㨂入して， $25 \pm 2^{\circ} \mathrm{C}$ で72時間拡散性水菜量在测した，乙れらの水素 をそれぞれ $\mathrm{D}_{1}, \mathrm{D}_{2}$ としその和を放出水素 (Evolved hydrogen）とした，この測定を終ったのち，スズ溶法

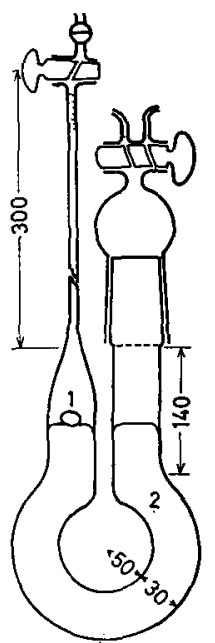

Fig. 18. An apparatus of IIW method.

1: Specimen

2: Mercury

Table 4. Chemical compositions of materials (\%).

\begin{tabular}{|c|c|c|c|c|c|c|c|}
\hline 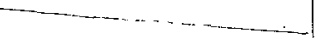 & $\mathrm{C}$ & Si & $\mathbf{M n}$ & $\mathrm{P}$ & $\mathrm{s}$ & $\mathrm{Ni}$ & $\mathrm{Cr}$ \\
\hline Pure iron & 0.003 & 0.002 & 0.015 & tr. & tr. & - & - \\
\hline Low carbon steel & 0.007 & 0.010 & 0.47 & 0.012 & 0.013 & 一 & 一 \\
\hline 1. $7 \% \mathrm{Mn}$ steel & 0.093 & 0.050 & 1.68 & 0.013 & 0.008 & $\longrightarrow$ & - \\
\hline 18-8 stainless steel & 0.028 & 0.28 & 1.33 & 0.014 & 0.009 & 8.73 & 19.05 \\
\hline 15-35 stainless steel & 0.059 & 0.26 & 1.70 & 0.013 & 0.015 & 4.703 & 14.75 \\
\hline
\end{tabular}


Table 5. Hydrogen partial pressure and absorbed hydrogen ( $\mathrm{ml} / 100 \mathrm{~g}$ ).

\begin{tabular}{|c|c|c|c|c|c|c|c|c|c|c|c|c|c|c|c|c|c|c|c|c|}
\hline \multirow{2}{*}{$\begin{array}{l}\mathrm{H}_{2} \\
\text { Pressure } \\
\quad \text { (atm) }\end{array}$} & \multicolumn{4}{|c|}{ Pure iron } & \multicolumn{4}{|c|}{ Low carbon steel } & \multicolumn{4}{|c|}{$1.7 \% \mathrm{Mn}$ steel } & \multicolumn{4}{|c|}{$\begin{array}{c}18-8 \text { stainless } \\
\text { steel }\end{array}$} & \multicolumn{4}{|c|}{$\begin{array}{c}\text { 15-35 stainless } \\
\text { steel }\end{array}$} \\
\hline & $\mathbf{D}_{1}$ & $\mathbf{D}_{2}$ & $\mathbf{R}$ & $T$ & $\mathbf{D}_{1}$ & $\mathrm{D}_{2}$ & $\mathbf{R}$ & $T$ & $\mathbf{D}_{1}$ & $\mathrm{D}_{2}$ & $\mathbf{R}$ & $\mathbf{T}$ & $\mathrm{D}_{1}$ & $\mathrm{D}_{2}$ & $\mathbf{R}$ & $T$ & $D_{1}$ & $\mathbf{D}_{2}$ & $\mathbf{R}$ & $T$ \\
\hline 0 & $\begin{array}{l}1.0 \\
1.2 \\
0.9 \\
(1.1)\end{array}$ & - & $\mid \begin{array}{l}0.1 \\
0.1 \\
0.1 \\
(0.1)\end{array}$ & 1.2 & $\begin{array}{c}0.6 \\
0.8 \\
0.8 \\
0.9 \\
(0.8)\end{array}$ & $\left|\begin{array}{c}0.0 \\
0.0 \\
0.0 \\
(0.0)\end{array}\right|$ & $\mid \begin{array}{c}0.1 \\
0.1 \\
0.1 \\
0.1 \\
(0.1)\end{array}$ & 0.9 & $\begin{array}{c}1.1 \\
1.2 \\
1.0 \\
1.3 \\
(1.2)\end{array}$ & $\left|\begin{array}{l}0.0 \\
0.1 \\
0.1 \\
(0.1)\end{array}\right|$ & $\left|\begin{array}{c}0.3 \\
0.2 \\
0.2 \\
0.2 \\
(0.2)\end{array}\right|$ & 1.5 & $\begin{array}{r}0.2 \\
0.4 \\
(0.3)\end{array}$ & - & $\left|\begin{array}{c}0.8 \\
1.6 \\
0.6 \\
0.9 \\
(1.0)\end{array}\right|$ & 1.3 & $\begin{array}{l}0.3 \\
0.3\end{array}$ & - & $\begin{array}{c}1.3 \\
1.0 \\
0.9 \\
1.5 \\
(1.2)\end{array}$ & 15 \\
\hline 0.03 & $\begin{array}{r}6.8 \\
7.3 \\
6.7 \\
(6.9)\end{array}$ & - & $\mid \begin{array}{c}0.2 \\
0.3 \\
0.2 \\
(0.2)\end{array}$ & 7.1 & $\begin{array}{c}6.7 \\
6.7 \\
7.0 \\
6.5 \\
(6.7)\end{array}$ & $\begin{array}{c}0.2 \\
0.1 \\
0.1 \\
(0.1)\end{array}$ & $\left|\begin{array}{c}0.3 \\
0.1 \\
0.1 \\
0.1 \\
(0.2)\end{array}\right|$ & 7.0 & $\begin{array}{c}7.4 \\
8.0 \\
7.3 \\
8.1 \\
(7.7)\end{array}$ & $\left|\begin{array}{l}0.7 \\
0.9 \\
1.0 \\
(0.9)\end{array}\right|$ & $\left(\begin{array}{c}1.2 \\
0.0 \\
0.7 \\
0.3 \\
(0.8)\end{array}\right)$ & 9.4 & $\begin{array}{c}4.8 \\
3.9 \\
4.5 \\
4.4 \\
(4.4)\end{array}$ & - & $\begin{array}{c}4.1 \\
3.0 \\
4.2 \\
4.4 \\
(3.9)\end{array}$ & 8.3 & $\begin{array}{c}4.2 \\
4.3 \\
5.5 \\
4.6 \\
(4.6)\end{array}$ & 一 & $\begin{array}{c}4.6 \\
4.1 \\
4.7 \\
5.0 \\
(4.6)\end{array}$ & 9.2 \\
\hline 0.05 & $\begin{array}{c}10.5 \\
9.9 \\
9.0 \\
8.3 \\
(9.4)\end{array}$ & - & $\left|\begin{array}{l}0.4 \\
0.1 \\
0.1 \\
(0.2)\end{array}\right|$ & 9.6 & $\begin{array}{c}8.8 \\
9.2 \\
8.0 \\
8.7 \\
(8.7)\end{array}$ & $\mid \begin{array}{l}0.2 \\
0.2 \\
0.1 \\
(0.2)\end{array}$ & $\begin{array}{c}1.4 \\
0.1 \\
0.7 \\
0.6 \\
(0.7)\end{array}$ & 9.6 & $\begin{array}{r}9.4 \\
9.2 \\
9.3 \\
(9.3)\end{array}$ & $\left|\begin{array}{c}1.4 \\
1.0 \\
1.2 \\
(1.2)\end{array}\right|$ & $\mid \begin{array}{c}1.0 \\
0.3 \\
0.6 \\
0.7 \\
(0.7)\end{array}$ & 11.2 & $\begin{array}{c}6.1 \\
6.4 \\
6.1 \\
5.8 \\
(6.1)\end{array}$ & 一 & $\mid \begin{array}{c}5.4 \\
5.0 \\
4.8 \\
5.3 \\
(5.1)\end{array}$ & 11.2 & $\begin{array}{c}7.2 \\
7.2 \\
7.5 \\
7.2 \\
(7.3)\end{array}$ & - & $\begin{array}{c}5.9 \\
5.1 \\
5.8 \\
6.6 \\
(5.9)\end{array}$ & 12.2 \\
\hline 0.10 & $\begin{array}{c}12.4 \\
12.3 \\
12.8 \\
12.6 \\
(12.5)\end{array}$ & - & $\left|\begin{array}{l}0.2 \\
0.4 \\
0.3 \\
(0.3)\end{array}\right|$ & 12.8 & $\begin{array}{c}13.1 \\
12.5 \\
13.4 \\
13.0 \\
(13.0)\end{array}$ & $\left|\begin{array}{l}0.2 \\
0.4 \\
0.3 \\
(0.3)\end{array}\right|$ & $\left|\begin{array}{c}0.1 \\
0.1 \\
0.1 \\
0.1 \\
(0.1)\end{array}\right|$ & 13.4 & $\begin{array}{c}12.1 \\
15.1 \\
14.9 \\
14.1 \\
(14.1)\end{array}$ & $\left|\begin{array}{c}1.6 \\
1.9 \\
1.8 \\
1.6 \\
(1.7)\end{array}\right|$ & $\left|\begin{array}{c}1.0 \\
0.7 \\
1.0 \\
0.7 \\
(0.8)\end{array}\right|$ & 16.6 & $\begin{array}{r}10.0 \\
9.9 \\
9.7 \\
9.4 \\
(9.8)\end{array}$ & - & $\left|\begin{array}{c}6.9 \\
6.0 \\
6.8 \\
6.5 \\
(6.6)\end{array}\right|$ & 16.4 & $\begin{array}{r}10.2 \\
10.2 \\
9.0 \\
9.8 \\
(9.8)\end{array}$ & - & $\begin{array}{c}6.9 \\
7.4 \\
7.2 \\
7.6 \\
(7.3)\end{array}$ & 17.1 \\
\hline 0.20 & $\begin{array}{c}17.8 \\
17.2 \\
17.8 \\
17.2 \\
(17.8)\end{array}$ & $\left|\begin{array}{l}0.0 \\
0.0 \\
0.0 \\
(0.0)\end{array}\right|$ & $\left|\begin{array}{l}0.5 \\
0.8 \\
0.5 \\
(0.6)\end{array}\right|$ & 18.4 & $\begin{array}{c}18.4 \\
19.3 \\
18.4 \\
19.3 \\
(18.9)\end{array}$ & {$\left[\begin{array}{c}0.1 \\
0.7 \\
0.4 \\
\\
(0.4)\end{array} \mid\right.$} & $\mid \begin{array}{c}1.0 \\
1.5 \\
0.6 \\
0.8 \\
(1.0)\end{array}$ & 19.4 & $\begin{array}{c}18.3 \\
18.2 \\
20.5 \\
18.7 \\
(19.0)\end{array}$ & $\mid \begin{array}{c}2.4 \\
3.1 \\
1.9 \\
2.6 \\
(2.4)\end{array}$ & $\left|\begin{array}{c}0.4 \\
1.9 \\
0.9 \\
0.4 \\
(0.8)\end{array}\right|$ & 22.2 & $\begin{array}{c}10.5 \\
12.0 \\
11.9 \\
11.8 \\
(11.6)\end{array}$ & $\left\{\begin{array}{l}0.0 \\
0.0 \\
(0.0)\end{array}\right.$ & $\mid \begin{array}{c}5.8 \\
6.8 \\
8.7 \\
7.4 \\
(7.2)\end{array}$ & 18.8 & $\begin{array}{c}12.2 \\
13.1 \\
12.2 \\
11.4 \\
(12.3)\end{array}$ & $\begin{array}{l}0.0 \\
0.0 \\
(0.0)\end{array}$ & $\mid \begin{array}{r}10.9 \\
10.6 \\
9.2 \\
9.4 \\
(10.0)\end{array}$ & 22.3 \\
\hline $\begin{array}{l}(): \mathbf{a v} \\
\mathbf{D}_{1}: \mathbf{D} \\
\mathbf{D}_{2}: \mathbf{D}\end{array}$ & $\begin{array}{l}\text { erage } v \\
\text { fusible } \\
\text { ffusible }\end{array}$ & $\begin{array}{l}\text { alue } \\
\text { hydr } \\
\text { hydr }\end{array}$ & $\begin{array}{l}\text { rogen } \\
\text { rogen }\end{array}$ & $\begin{array}{l}\text { (by } \\
\text { (by }\end{array}$ & $\begin{array}{l}\text { this ap } \\
\text { IIW me }\end{array}$ & $\begin{array}{l}\text { paratu } \\
\text { ethod) }\end{array}$ & us) & $\begin{array}{l}\mathrm{R}: \\
\mathrm{T}: \mathrm{I} \\
-:\end{array}$ & $\begin{array}{l}D_{1}+D_{2} \\
\text { not ex }\end{array}$ & $+R$ & Total & 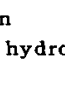 & ogen) & & & & & & & \\
\hline
\end{tabular}

によって残留水素を定量し，以上 3 種の測定値の合計を 全溶解水素量 (Total hydrogen) とした.

\section{2 溶解水素最}

T I Gアーク溶融した供試金属への溶解水素量之需围 気の水素分压の関係を Table 5 に, $\sqrt{\mathrm{P}_{\mathrm{H}_{2}}}$ で整理した 結果を Fig. 19２3 亿示す.

Fig. 24 26 は放出水素量, 残留水素量および全溶解 水素量おのおのについてもとめたものである.

てれらから明らかなように，いずれの場合も溶解水素 量は実験した $\mathrm{P}_{\mathrm{H}_{2}} \leqq 0.2 \mathrm{~atm}$ の範囲で Sieverts の法則 にしたがうことがわかった。

電解鉄における溶解水素量之水素分压の関係は次式で あらわされる。

$$
\underline{\mathrm{H}}(\mathrm{ppm})=37.8 \sqrt{\mathrm{P}_{\mathrm{H}_{2}}}
$$

$\mathrm{P}_{\mathrm{H}_{2}}>0.2 \mathrm{~atm}$ についても Sieverts の法則が適用で きるとすれぱ， $\mathrm{P}_{\mathrm{H}_{2}}=1 \mathrm{~atm}$ に相当する溶解水素量は， $\underline{H}=37.8 \mathrm{ppm}$ になり，てれは Weinstein \& Elliott の 製鋼反応における鉄の溶解水素量 ${ }^{5}$ 加ら外挿すると 2020 ${ }^{\circ} \mathrm{C}$ における溶解度に相当する。

$18 \mathrm{Cr}-8 \mathrm{Ni}$ ステンレス鋼については, $\mathrm{P}_{\mathrm{H}_{2}}=1 \mathrm{~atm} に$
おける溶解水素量は $43.7 \mathrm{ppm}$ になり，乙れは $2050^{\circ} \mathrm{C}$ における溶解度に相当する.

供試鋼の組成加引水素の活量係数に上る活量補正を行 なって次式に示す Schenck の式おおよび Weinstein \& Elliott $の$ 式 $^{5}$ 加ら平衡温度を求めると Table 6 のよう になった。

$$
K=2.75 \times 10^{-6} t^{\circ} \mathrm{C}-175.5 \times 10^{-5} \text { (Schenck) }{ }^{4}
$$

$\log K=(-1905 / T)-1.591$ (Weinstein \& Elliott) ${ }^{5)}$

いずれの式を用いてすＴ１Gアーク溶融における平衡 温度は，1.7\%マンガン鋼を除いて $2000 \sim 2100^{\circ} \mathrm{C}$ にな り, Howden $ら^{3)}$ の求めた $2100^{\circ} \mathrm{C}$ および Salter ${ }^{23}$ の 求めた $1900^{\circ} \mathrm{C}$ とよく一致した。

$1.7 \%$ マンガン鎆の平衡温度は $2190^{\circ} \mathrm{C}$ でやや高い温 度を示した。

Fig. 25 は残 留水妻量の材質による比較であり，ステ ンレス鋼では電解鉄や低炭素鋼に比べてははなはだしく 大きな值を示した．とれはオーステナイト鋼の水素溶解 度が大きいこと，㹡散速度がきめて遅いためと考えられ る。

残留水素も $\sqrt{\mathrm{P}_{\mathrm{H}_{2}}}$ に比例して増加し, 鋼中の水素の 


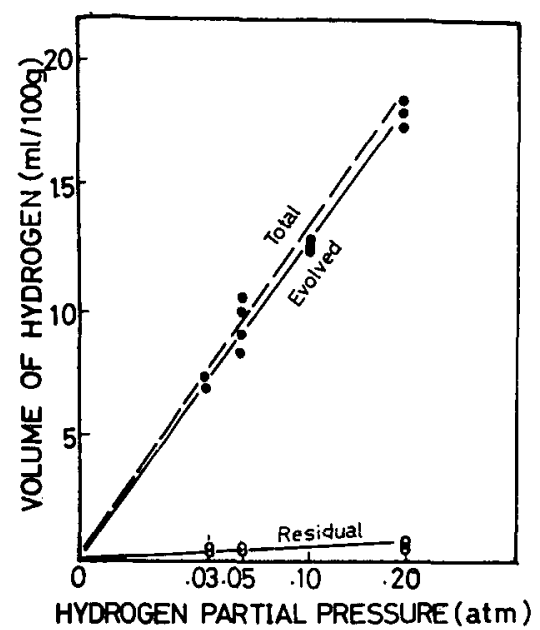

Fig. 19. Hhydrogen absorption in pure iron.

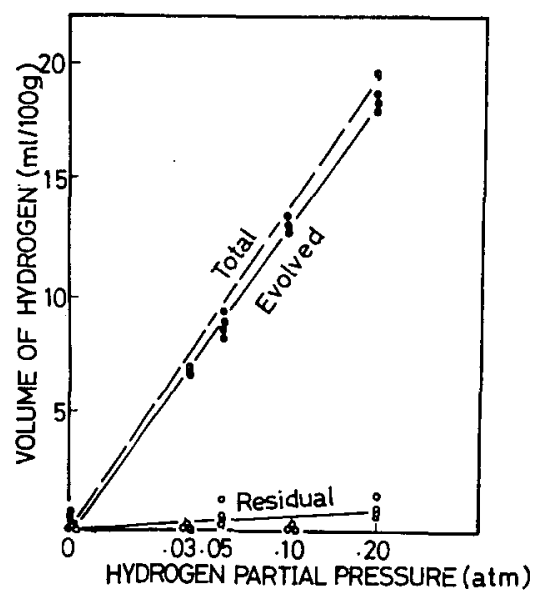

Fig. 20. Hydrogen absorptin in low carbon steel.

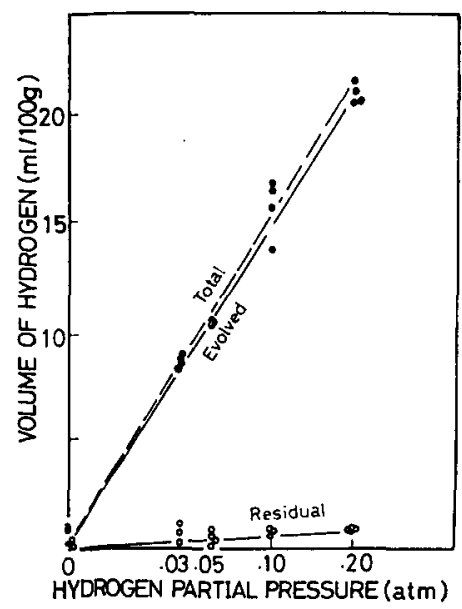

Fig. 21. Hydrogen absorption in $1.7 \% \mathrm{Mn}$ steel.

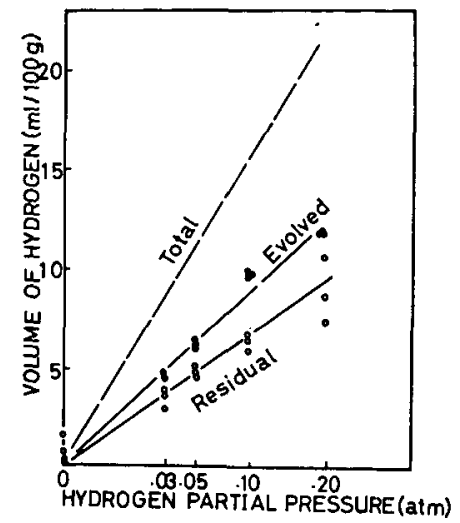

Fig. 22. Hydrogen absorption in 18-8 stainless steel.

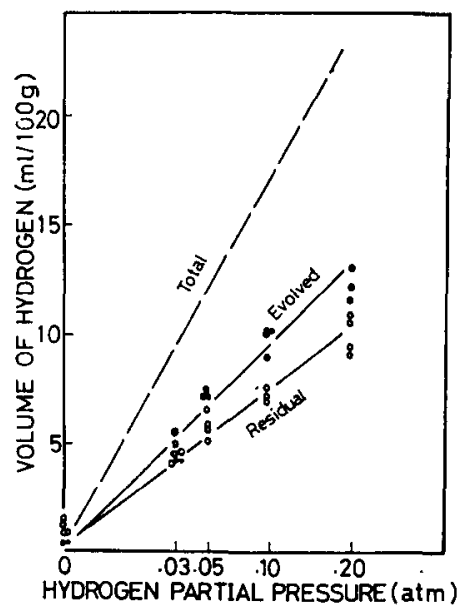

Fig. 23. Hydrogen absorption in 15-35 stainless steel.

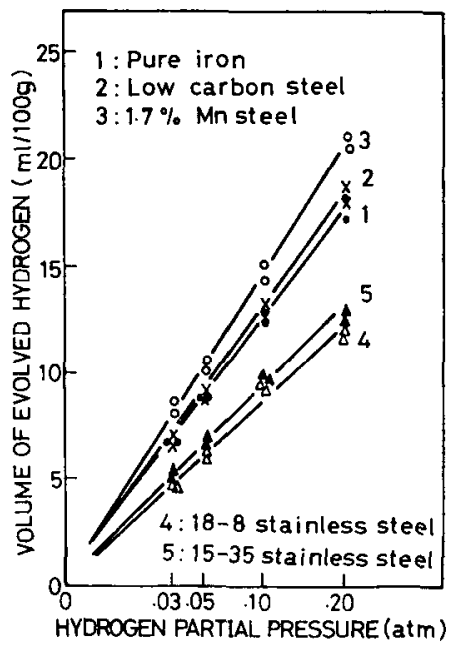

Fig. 24. The effect of material composition on the evolved hydrogen. 


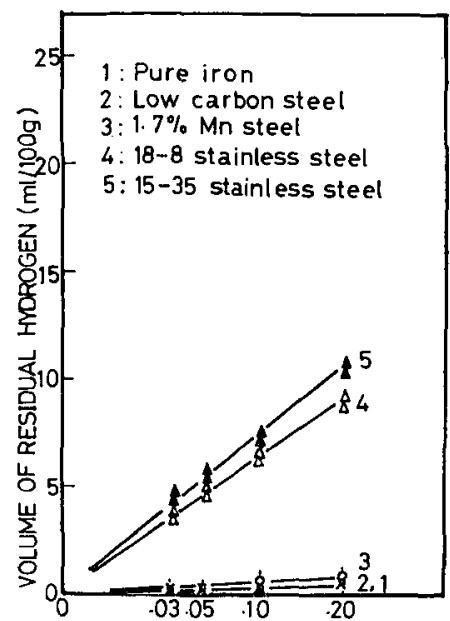

HYDROGEN PARTIAL PRESSURE (atm)

Fig. 25. The effect of material compsoition on the residual hydrogen.

trap site の密度がかなり大きいととを示しており，乙 の比例定数が Table 7 である. Table 5 からあ明らか なように，オーステナイト鋼に対して 3 種のフエライト 鋼の残留水素はきわめて少ないので，分析精度の点から 比例定数を決定するのは困難であった.

\section{3 水素の放出過程}

アーク溶融した溶鋼からの消弧後の水素放出挙動を Fig. 27 に示す. 溶解水㨞は消弧後すみやかに放出さ れ，低岩素鋼の場合， $\mathrm{P}_{\mathrm{H}_{2}}$ に関係なく消弧後 $20 \mathrm{~s}$ で溶 解水素量のほぼ1 $/ 2 か ゙ ， 5 \mathrm{~min}$ 間で $90 \%$ 以上が放出され た.オーステナイトステンレス鋼の場合は，放出水素量 之残留水素の比が約10：7であり，多くの水素を残留す るが，放出水素について考えると低炭素鋼よりきわめて

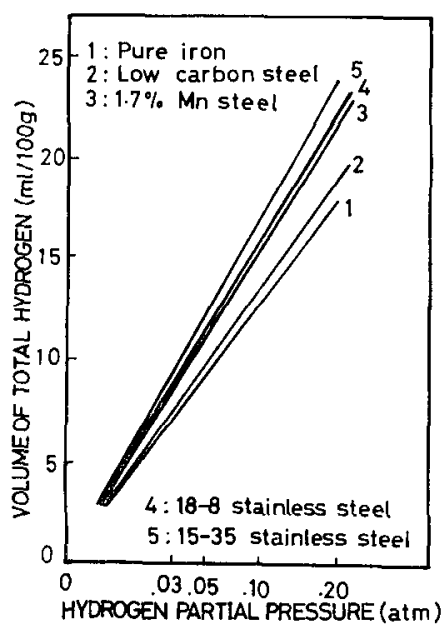

Fig. 26. The effect of material composition on the total hydrogen.

短時間に放出を完了し，との大部分は疑固に之もなって 放出された水素と考えられる.

\section{4 まटめ}

T I Gアーク溶融に斿ける溶接雾囲気 $\left(\mathrm{P}_{\mathrm{H}_{2}} \leqq 0.2\right.$ $\mathrm{atm})$ 之溶解水素量の関係を鋼種をかえて実験し，つぎ の結果が得られた。

1. 水菜溶解はすべての供試鋼に括いて Sieverts の 法則にしたがい，その比例定数が求まった。

2. T I Gアーク溶融における溶解水素量飞製鋼反応 の平衡式を適用すると平衡温度は $1.7 \%$ マンガン鋼 を除いて $2000 \sim 2100^{\circ} \mathrm{C}$ になり，ほかの測定者の結 果尚3)之一致した。

$1.7 \%$ マンガン鋼の場合には $2190^{\circ} \mathrm{C}$ になり,やや

Table 6. Quasiequilibrium temperature on the hydrogen absorption $\left({ }^{\circ} \mathrm{C}\right)$.

\begin{tabular}{|c|c|c|c|c|}
\hline & \multicolumn{2}{|c|}{$\mathrm{P}_{\mathrm{H}_{2}}=1$ atm } & \multirow{2}{*}{ Schenck ${ }^{4)}$} & \multirow{2}{*}{$\begin{array}{l}\text { Weinstein } \\
\text { \& Elliott }\end{array}$} \\
\hline & $\underline{H}(\mathbf{p p m})$ & $a^{*}(\mathrm{ppm})$ & & \\
\hline Pure iron & 37.8 & 37.8 & 2010 & 2010 \\
\hline Low carbon steel & 38.5 & 38.7 & 2050 & 2040 \\
\hline $1.7 \% \mathrm{Mn}$ steel & 43.1 & 42.7 & 2190 & 2190 \\
\hline $18-8$ stainless steel & 43.7 & 39.3 & 2070 & 2070 \\
\hline 15-35 stainless steel & 47.3 & $\longrightarrow$ & - & - \\
\hline
\end{tabular}

*a-activity of hydrogen

Table 7 Relation between $\mathrm{PH}_{2}$ and residual hydrogen.

\begin{tabular}{c|c|c|c|c|c}
\hline Material & $\begin{array}{c}\text { Pure } \\
\text { iron }\end{array}$ & $\begin{array}{c}\text { Low } \\
\text { carbon } \\
\text { steel }\end{array}$ & $\begin{array}{c}1.7 \% \mathrm{Mn} \\
\text { steel }\end{array}$ & $\begin{array}{c}18-8 \\
\text { stainless } \\
\text { steel }\end{array}$ & $\begin{array}{c}15-35 \\
\text { stainless } \\
\text { steel }\end{array}$ \\
\hline$K$ & small & small & small & 19.2 & 20.8 \\
\hline
\end{tabular}




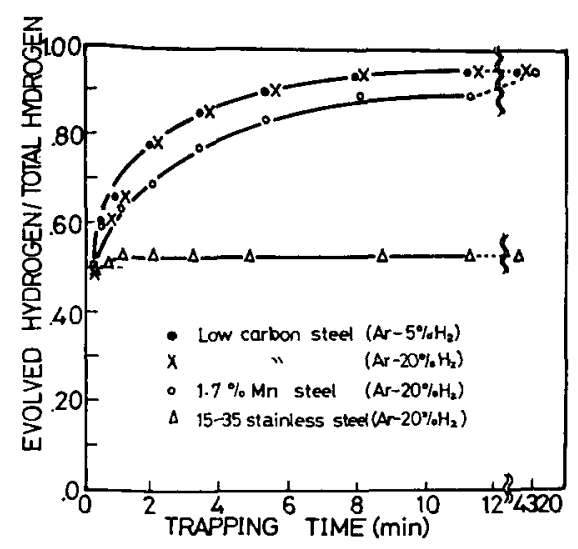

Fig. 27. The rate of hydrogen evolution. (specimen weight $7 \mathrm{~g}$, arc current $150 \mathrm{~A}$, arc time $30 \mathrm{~s}$ )

高い温度を示した。

3.上述の結果は, 溶融金属組成による水素の活量補 正を行なったあので，乙の補正によって水素溶解は 組成に関係なく同等にとりあつかうととができる.

4. 溶滴に溶解した水素は消弧後すみやかに減少し， $20 \mathrm{~s}$ で約 $1 / 2$ になる. $5 \mathrm{~min}$ 後には, 低炭素鋼では 約 $98 \%$ ，ステンレス鋼では $100 \%$ の放散性水菜が放 出される。

\section{5. 結 論}

J I S 拡散性水素試験結果汇影響する諸要因について 検討し，ついで消弧之同時に溶解水菜量を正確に測定で きる新しい装置を考案し，鉄および鉄合金をアーク溶融 したときの溶解水素量を調べた。

得られた結論はつぎのでとくである.

1. J I S 水素試験による拡散性水素測定結果は, 溶 接速度が一定でも溶接時間により極大值を生じる. 溶接速度が $3.8 \mathrm{~mm} / \mathrm{s}$ の上きには, 溶接時間 $20 \mathrm{~s}$ で最大溶解量を示した。

2. J I S 水菜試験結果は, 溶着金属重量基準で表示 するよりも，溶込量を考虑して溶接金属重量基準で 表示するほうが合理的であり，この事実は溶融池で の水素溶解拉よび放出が支配的であるこよを示唆し ている.

3. 純溶着金属の拡散性水素量の測定值は J I S 法の 数分の 1 亿すぎない。
4. 以上の結果から，J I S 法による拡散性水素量が かなりの部分は母材中に拡散した水菜量であると考 えられる。

5. 溶着金属の水菜量を正確に知るためには，母材を 用いない適当量の純溶着金属にたいして消弧之同時 に测定を開始できる装置が必要である.

6. $0.2 \sim 1.5 \mathrm{ml}$ の水素量を誤差 $0.03 \mathrm{ml}$ 以下で, 消弧と同時に測定を始められる装置を製作すること ができた.

7. アーク雾囲気の水素濃度に関係なく, 溶融池での 水索溶解は点弧時間 $10 \mathrm{~s}$ で定常状態に達するとと かわかった.

8. 溶接電流 $110 \sim 190 \mathrm{~A}$ で, 溶解水素量の電流によ る場加は $0.0038 \mathrm{ml} / 100 \mathrm{~g} \cdot \mathrm{A}$ でありきわめて少な い.

9. $\mathrm{P}_{\mathrm{H}_{2}} \leq 0.2 \mathrm{~atm}$ において, 電解鉄, 低炭素鋼, $1.7 \%$ マンガン鋼, オーステナイトステンレス鋼な どのアーク溶融時の水素溶解は Sieverts の法則に したがうことが明らかになり，その比例定数が求ま った.

10. アーク溶融時の溶解水素量に製鋼反応の平衡式を 適用すれば，上述のすべての供試銅の平衡温度は $2000 \sim 2200^{\circ} \mathrm{C}$ になる. 乙の場合，溶融金属の組成 による活量補正を行なう必要がある.

11. 溶解水素量の消弧後の減少は速く，20s 後には約 1/2になり, $5 \mathrm{~min}$ 後には少なくとも $95 \%$ 以上が放出 されてしまう。

おわりに，本論文をまこめるにあたり，大阪大学教授 菊田米男博士から有益な討議を睗わりました。ことに記 して厚く御礼申し上げます.

\section{参考 文 献}

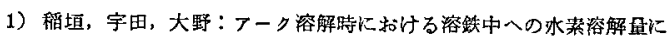
つい, , 本会予稿集, $7(1970), 29$.

2) G.R. Salter; Hydrogen absorption in arc melting, Brit. Weld. J., 10-6 (1963), 316

3) D.G. Howden \& D.R. Milner; Hydrogen absorption in arc melting, Brit, Weld. J., 10-6 (1963), 304

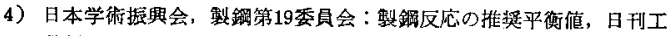
業新聞社, (1958)，150.

5) M. Weinstein \& J.F. Elliott; Solubility of hydrogen in liquid iron alloys, Trans. Met. Soc. AIME., 277 (1963), 382 